\title{
Acute Effects of Lead on the Renal Handling of Zinc in Dogs
}

\author{
Winona Victer y, ${ }^{1}$ Neil E. Soifer, Jonathan S. Weiss, and ARThur J. Vander ${ }^{2}$ \\ Department of Physiology, University of Michigan, Ann Arbor, Michigan 48109
}

Received April 20, 1981; accepted June 24, 1981

\begin{abstract}
Acute Effects of Lead on the Renal Handling of Zinc in Dogs. VICTERY, W., Solfer, N. E., Weiss, J. S., And Vander, A. J. (1981). Toxicol. Appl. Pharmacol. 61, 358-367. Urinary zinc excretion was monitored in anesthetized dogs before and during $4 \mathrm{hr}$ after acute exposure to lead (doses: $0.3 \mathrm{mg} \mathrm{Pb}$ (as acetate) $/ \mathrm{kg}$ as iv prime, followed by infusion of 0.057 $\mathrm{mg} \mathrm{Pb} / \mathrm{min} ; 3 \mathrm{mg} \mathrm{Pb} / \mathrm{kg}$, followed by $0.57 \mathrm{mg} \mathrm{Pb} / \mathrm{min}$ as infusion; or equimolar sodium acetate in the control group). Zinc excretion in time controls was relatively constant over the $4 \mathrm{hr}$, but it rose above baseline values an average of $140 \mathrm{ng} / \mathrm{min}$ in $0.3 \mathrm{mg} \mathrm{Pb} / \mathrm{kg}$ injected animals, and an average of $300 \mathrm{ng} / \mathrm{min}$ in $3 \mathrm{mg} \mathrm{Pb} / \mathrm{kg}$ injected animals. Other indices of renal function, including excretion of protein, $\mathrm{Na}, \mathrm{K}$, and $\mathrm{Mg}$, were relatively constant. Plasma $\mathrm{Zn}$ concentration was stable in time control and low Pb-administered animals, but rose significantly after the higher $\mathrm{Pb}$ dose. Clearance experiments using ${ }^{65} \mathrm{Zn}$ and in vitro ultrafiltration of plasma were performed in another series of dogs under antidiuretic conditions. Zn excretion (monitored by ${ }^{65} \mathrm{Zn}$ ) was scvenfold higher in Pb-treated dogs; plasma $\mathrm{Zn}$ concentration was slightly, but not significantly, elevated. Ultrafiltrable $\mathrm{Zn}$ concentration was 2.5 -fold higher and fractional $\mathrm{Zn}$ excretion was three times higher in $\mathrm{Pb}$-treated dogs. The stop-flow pattern for $\mathrm{Zn}$ after $\mathrm{Pb}$ treatment showed no change in the distal tubular handling of $\mathrm{Zn}$, but revealed prominent net proximal tubular secretion of $\mathrm{Zn}$ in all animals, a frequency statistically different from that observed in control animals. Thus, acute $\mathrm{Pb}$ treatment in dogs produced an increase in urinary $\mathrm{Zn}$ excretion which was related both to an increase in ultrafilterable plasma $\mathrm{Zn}$ and a change in renal tubular $\mathrm{Zn}$ transport. The plasma concentrations of insulin and glucagon were not altered by lead.
\end{abstract}

The purpose of this study was to determine whether lead can alter the renal excretion of the essential trace element, zinc. A number of studies have documented that the chronic administration to rats of large quantities of zinc (either in the diet or drinking water) can reduce the concentrations of lead in blood and other tissues (Cerklewski and Forbes, 1976; Thawley et al., 1977; El-Gazzar et al., 1978; Cerklewski, 1979). These changes were associated with a protective

\footnotetext{
${ }^{1}$ Present address: Laboratory of Pharmacology, National Institute of Environmental Health Sciences, P.O. Box 12233, Research Triangle Park, N.C. 27709.

${ }^{2}$ Address correspondence to: Arthur J. Vander, Department of Physiology, 6811 Medical Science II, University of Michigan, Ann Arbor, Mich. 48109.
}

effect against the effects of lead on heme synthesis (Cerklewski and Forbes, 1976; Thawley et al., 1977). This protective effect is very likely due not only to the diminished body burden of lead, but to a direct interaction between lead and zinc on certain enzymes, e.g., amino levulinic acid dehydratase (Meredith et al., 1977; Cantrell et al., 1977; Davis and Avram, 1978; Mauras and Allain, 1979). Paradoxically, the chronic administration of extremely large amounts of zinc to pigs (Hsu et al., 1975) and horses (Hsu et al., 1975) produced an increase in blood and soft-tissue lead, with either an increase in lead toxicity (Hsu et al., 1975) or a decrease (Willoughby et al., 1972).

To our knowledge there have been only two studies of the reverse relationship, i.e., 
the effects of lead on zinc metabolism. In a study of mice, Seth et al. (1976) found no effect of lead administration on the concentrations of zinc in kidney and liver; El-Gazzar et al. (1978), in a larger study with rats, found that the addition of $100 \mathrm{ppm} \mathrm{Pb}$ to drinking water caused a decrease in plasma, liver, and bone zinc concentrations. In neither study was urinary excretion of zinc measured.

We have previously reported that both lead (Vander et al., 1977; Victery et al., 1979a,b) and zinc (Victery et al., 1981) undergo glomerular filtration and tubular reabsorption, and probably also tubular secretion. The reabsorption sites for these two elements are coextensive, raising the possibility that lead and zinc might compete for tubular transport pathways. It is also possible that some competition might exist between them for the low-molecular-weight ligands in plasma that permit their ultrafilterability. These facts, taken together with the $\mathrm{Pb}-\mathrm{Zn}$ interactions described above, suggest the hypothesis that lead would alter the renal excretion of zinc. To test this hypothesis, and to obtain information concerning the mechanism of any observed change, we utilized renal clearance and stop-flow techniques in anesthetized dogs. The plasma concentrations of glucagon and insulin were also studied, since we have previously shown that glucagon can enhance zinc excretion (Victery et al., 1980); a rise in the plasma concentrations of these hormones might be expected since the hepatic clearance of another protein hormone, renin, is reduced under the conditions of these experiments (Goldman et al., 1980).

\section{METHODS}

Series $A$. Studies were performed on 15 nonfasted male dogs weighing $15-21 \mathrm{~kg}$. The dogs were anesthetized with pentobarbital $(30 \mathrm{mg} / \mathrm{kg}$ iv, with supplements given as required) and were prepared surgically for renal clearance experiments. Both cephalic veins, a femoral vein, and an artery were catheterized, as was the right ureter via a small flank incision. After completion of surgery, each dog received an iv prime of $p$-aminohippurate $(\mathrm{PAH})$ and creatinine $(0.25$ and $0.6 \mathrm{~g}$, respectively), dissolved in $20 \mathrm{ml}$ saline, followed by an infusion of approximately $6 \mathrm{mg} / \mathrm{min}$ of each substance in a total of $0.21 \mathrm{ml}$ isotonic saline $/ \mathrm{min}$. Following a 1 -hr equilibration period, sequential 15 -min urine collections were obtained from the ureteral catheter during the next 5 $\mathrm{hr}$; each clearance value to be reported is the average of two consecutive 15 -min collections. Twenty-milliliter arterial blood samples (replaced with an equal volume of isotonic saline) were obtained $45 \mathrm{~min}$ into each $\mathrm{hr}$. All blood samples were immediately chilled and centrifuged at $4^{\circ} \mathrm{C}$, and the plasma was frozen.

The first of the five hourly periods was a baseline period for all dogs. Following this, five dogs (high- $\mathrm{Pb}$ ) received, over $10 \mathrm{~min}, 3 \mathrm{mg} \mathrm{Pb}$ (as $\mathrm{Pb}$ acetate) $/ \mathrm{kg}$ iv as a prime dissolved in $10 \mathrm{ml} 5 \%$ dextrose, followed by an infusion of $0.57 \mathrm{mg} \mathrm{Pb}$ (as acetate) $/ \mathrm{min}$ in $0.21 \mathrm{ml}$ of $5 \%$ dextrose. Five dogs (low- $\mathrm{Pb}$ ) received one-tenth the dose of lead (prime $0.3 \mathrm{mg} \mathrm{Pb} / \mathrm{kg}$, followed by infusion of $0.057 \mathrm{mg} \mathrm{Pb} / \mathrm{min}$ ), with sodium acetate added to obtain a solution equimolar in acetate to the high-Pb dose. The five remaining dogs served as time controls and received a sodium-acetate prime and infusion, equimolar in acetate to the high- $\mathrm{Pb}$ dose. Throughout the experiment, mean arterial pressure, respiratory rate, hematocrit, and rectal temperatures were recorded.

Series $B$. In another group of four dogs, ${ }^{65} \mathrm{Zn}$ was used to permit the performance of stop-flow analysis (Victery et al., 1979b) and the determination of ultrafilterable zinc after the administration of $\mathrm{Pb}(3 \mathrm{mg} /$ $\mathrm{kg}$ ). As described in detail elsewhere (Victery et al., 1980,1981 ), the use of ${ }^{65} \mathrm{Zn}$ permits measurement of the very small concentrations of urinary zinc present during the high rates of urine flow characteristic of stopflow analysis; it also avoids zinc contamination of in vitro filtration materials and facilitates measurement of the very small quantity of plasma zinc which is ultrafilterable (Victery et al., 1980, 1981). Animals were prepared surgically as described for series A, except that one additional venous catheter was placed in a saphenous vein for infusion of ${ }^{65} \mathrm{Zn}$, and inulin rather than PAH was administered. ${ }^{65} \mathrm{Zn}$ infusion was given in isotonic saline at $0.21 \mathrm{ml} / \mathrm{min}$; it contained carrier $\mathrm{Zn}$ at $10 \mu \mathrm{g} \mathrm{Zn} / \mathrm{kg} / \mathrm{min}$ and $0.30 \mathrm{mCi}{ }^{65} \mathrm{Zn} / \mathrm{hr}$. The ${ }^{65} \mathrm{Zn}$ infusion was begun $1.5-2 \mathrm{hr}$ following the $\mathrm{Pb}$ dose and $1 \mathrm{hr}$ prior to the beginning of clearance collections. After this hour; two 15-min urine collections were obtained while the animals were in the same antiduretic state as the animals of series A. An infusion of $15 \%$ mannitol in isotonic saline at $0.75 \mathrm{ml} / \mathrm{min} / \mathrm{kg}$ was then begun, and after stabilization of urine flow at $7-10 \mathrm{ml} / \mathrm{min}$ (30-40 min after starting the mannitol), two 5-min urine collections were obtained. During both the antidiuretic and mannitol clearance periods, two $15-\mathrm{ml}$ vacutainers of nonanticoagulated blood were obtained and spun im- 
mediately for separation of plasma. Ultrafiltrates of plasma were prepared (Vander et al., 1977) using Amicon CF-50A (molecular weight cutoff 50,000) Centriflo membranes under $240 \mathrm{~g}$ centrifugation. All filtrates were checked for protein (dipstick method) and values discarded if they exceeded $1+(<20 \mathrm{mg} / \mathrm{dl})$. Samples of blood, plasma, filtrate, and urine were placed in tared tubes for ${ }^{65} \mathrm{Zn}$ counting. Urinary ${ }^{65} \mathrm{Zn}$ excretion and percentage of plasma ${ }^{65} \mathrm{Zn}$ which was ultrafilterable were determined from these counts; the increments in both "cold" $Z$ n excretion and the plasma and ultrafilterable concentrations of "cold" zinc produced by the carrier zinc infusion were calculated from the specific activity of the dose. No attempt was made to measure endogenous $\mathrm{Zn}$ concentrations in these experiments.

After completion of the mannitol clearances, a standard stop-flow procedure was performed (Malvin and Wildc, 1973): two or three urine samples ("frec-flow" samples) were collected over $30 \mathrm{sec}$, and immediately thereafter the ureteral catheter was completely occluded for $5 \mathrm{~min}$; following release of the occlusion, urine was collected in 30-50 sequential aliquots, each approximately $0.5 \mathrm{ml}$ ("stop flow" [SF] samples). The concentration of ${ }^{65} \mathrm{Zn}$ in each stop-tlow samples was divided by the $\left[{ }^{65} \mathrm{Zn}\right]$ in the free-flow (FF) samples preceding the occlusion, and this ratio, $[\mathrm{Zn}]_{\mathrm{SF}} /[\mathrm{Zn}]_{\mathrm{FF}}$, was divided by the analogous ratio for inulin, $[\operatorname{In}]_{\mathrm{SF}} /[\operatorname{In}]_{\mathrm{FF}}$. The values obtained by this double ratio calculation reflect sequential changes in $[\mathrm{Zn}]_{\mathrm{SF}}$ relative to free-flow after elimination of any concentration changes due solely to water reabsorption. A value of this double ratio greater than unity signifies net zinc secretion into that sample during ureteral occlusion; a value less than unity signifies the occurrence of net $\mathrm{Zn}$ reabsorption from that sample.

The timing and protocols of both the clearances and stop-flow procedures of series B were set to mimic precisely a large series (14 dogs) of time control experiments performed simultaneously in our laboratory in association with other studies (Victery et al., 1980, 1981); these 14 dogs had received precisely the same surgical preparation and infusions, and had clearances and stop-flow analysis performed at exactly the same length of time after the onset of the infusion of ${ }^{65} \mathrm{Zn}$ and inulin. Accordingly, this group of animals has been used as the control group to compare the effects of lead on the present dogs of series B. Such a control group is necessary since stop-flow analysis cannot be performed both before and after lead exposure, i.e., the $\mathrm{Pb}$ exposed dogs cannot act as their own controls.

Analytical methods. Urinary and plasma concentrations of zinc were measured by atomic absorption (Varian Instruments, Model 375, $214 \mathrm{~nm}$, slit =0.5); urinary magnesium concentration was also measured by atomic absorption $(202.5 \mathrm{~nm}$, slit $=0.5)$. Urine sodium and potassium concentrations were determined by flame photometry. Urinary and/or plasma concentrations of protein, creatinine, PAH, and inulin were determined by standard methods described previously (Victery et al., 1979a). Plasma concentrations of glucagon and insulin were measured by radioimmunoassay (Hayaski $e t$ al., 1977; Pek et al., 1972).

The values for excretion of zinc, magnesium, protein, sodium, and potassium, and for glomerular filtration rate (GFR) and effective renal plasma flow (ERPF) were averaged for each 0.5 -hr period (two consecutive 15-min collections) and treated as a single value.

All grouped data are presented as the mean \pm one standard error (SE). Statistical comparisons in the Series $A$ experiments are between experimental and time control groups, using regression analysis with Scheffé allowances for multiple comparisons. In series $\mathrm{B}$, differences between $\mathrm{Pb}$-treated and control animals were compared using Student's $t$ test for group mean, or $\chi^{2}$ for frequency data.

\section{RESULTS}

\section{Series $A$}

Figure 1 depicts the pattern of urinary zinc excretion over time in each of the three

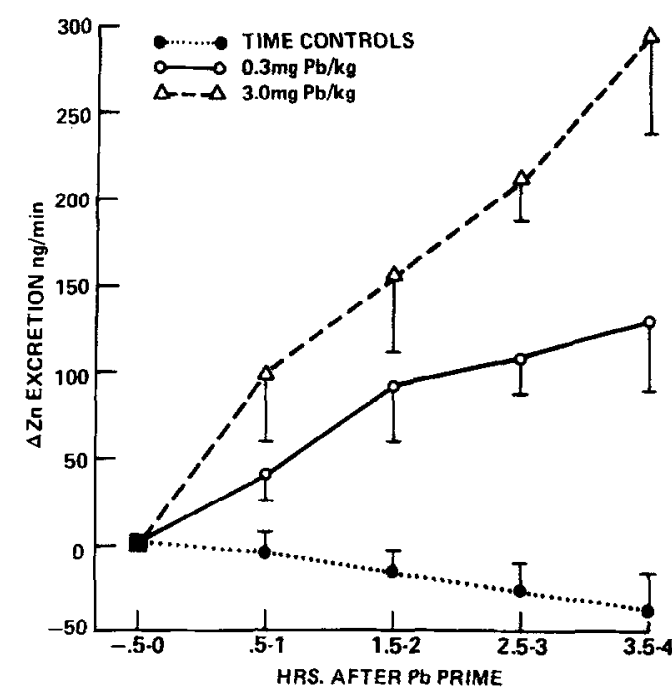

FIG. 1. Changes in urinary zinc excretion for the three groups of dogs are plotted against time after administration of the $\mathrm{Pb}$ or acetate prime. Excretion in the baseline half-hour clearance period $(-0.5-0 \mathrm{hr})$ has been set at zero, with successive time points plotted as the mean change from this baseline value (control dogs $=88.9 \pm 30.9$, low- $\mathrm{Pb}=46.5 \pm 7.0$ and high $-\mathrm{Pb}=49.5$ \pm 3.8). See text for statistical analysis of data. 
experimental groups of Series A. For clarity, excretion during the baseline clearance period $(-0.5-0 \mathrm{hr})$ has been set at zero; values of subsequent collections are the mean change $( \pm 1 \mathrm{SE})$ in $\mathrm{Zn}$ excretion for each group. $\mathrm{Zn}$ excretion, in nanograms per minute, for the baseline clearances for control dogs averaged $88.9 \pm 30.9$, low-Pb animals $=46.5 \pm 7.0$, and high $-\mathrm{Pb} 49.5 \pm 3.8$. There were no significant differences between these baseline group means; the larger mean for the control animals was attributable primarily to one animal whose initial zinc excretion was $200 \mathrm{ng} / \mathrm{min}$. Over the remaining 4-hr time course of the experiment, zinc excretion in control animals tended to decrease; the mean decrease at $4 \mathrm{hr}$ was 36 $\mathrm{ng} / \mathrm{min}$. In contrast, zinc excretion in both $\mathrm{Pb}$-treated groups rose dramatically and continuously beginning $0.5 \mathrm{hr}$ after lead exposure. Four hours after the high- $\mathrm{Pb}$ dose, zinc excretion was $294.3 \pm 56.0 \mathrm{ng} / \mathrm{min}$ above the baseline clearance value (a sevenfold increase). Four hours after the low$\mathrm{Pb}$ dose, zinc excretion was $138.8 \pm 51.4$ $\mathrm{ng} / \mathrm{min}$ greater than before $\mathrm{Pb}$ exposure (a fourfold increase). Comparison of the slopes of the curves for treated animals to that of controls yielded a $p$ value for the low dose of $<0.01$, and $<0.0002$ for the high dose.

Figure 2 presents the changes in plasma zinc concentrations; again, all values have been normalized with respect to the first (baseline) values; there were no differences between the baseline group means (control $=65.0 \pm 4.5 \mu \mathrm{g} / 100 \mathrm{ml}$; low dose $=70.6$ \pm 7.4 ; high dose $=67.6 \pm 14.5$ ). Plasma zinc in control animals fell slowly throughout the experiment, and at $4 \mathrm{hr}$ was about $20 \mu \mathrm{g} / 100 \mathrm{ml}$ lower than the baseline value. We have consistently observed this pattern in control animals; the cause is unknown but may relate to the trauma of anesthesia and surgery. Plasma zinc in animals which received the low dose of $\mathrm{Pb}$ tended to remain quite stable over time, and this pattern was not significantly different from that for the time controls. The larger dose of $\mathrm{Pb}$ pro-

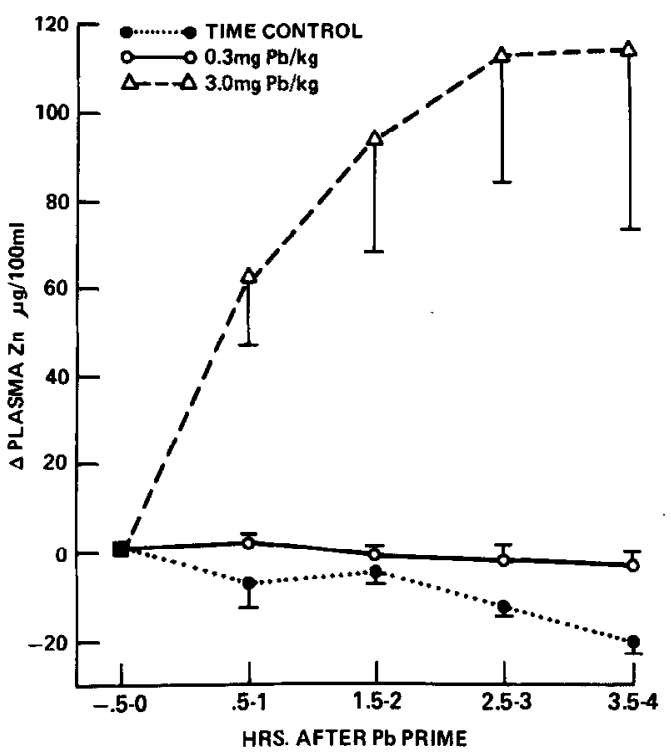

FIG. 2. Changes in plasma zinc concentration are plotted against time after $\mathrm{Pb}$ or acetate prime. Values for the baseline blood collection $(-0.5-0 \mathrm{hr})$ have been normalized to zero, with subsequent values plotted as the change from this baseline value (control dogs $=65.0$ $\pm 4.5 \mu \mathrm{g} / 100 \mathrm{ml}$, low $\mathrm{Pb}=70.6 \pm 7.4$, high $\mathrm{Pb}=67.6$ \pm 14.5 ). See text for statistical analysis of data.

duced a marked, significant $(p<0.01)$ rise in plasma zinc concentration over time; by $1 \mathrm{hr}$, there was a $64 \mu \mathrm{g} / 100 \mathrm{ml}$ increase, and by $4 \mathrm{hr}$, the increase was $113 \mu \mathrm{g} / 100 \mathrm{ml}$ (a two- to threefold increase).

The increase in plasma zinc might be due to displacement of zinc from erythrocytes to plasma. To test this possibility, a small sample of whole anticoagulated blood was removed from a dog before $\mathrm{Pb}$ treatment. To one aliquot of the blood, sufficient $\mathrm{Pb}$ acetate was added in vitro to increase $\mathrm{Pb}$ concentration by $400 \mu \mathrm{g} / 100 \mathrm{ml}$ (the estimated blood concentration of lead present $2 \mathrm{hr}$ after the lead prime). Both aliquots were incubated at $37^{\circ} \mathrm{C}$ for $1 \mathrm{hr}$, then centrifuged to separate the plasma. There was no difference in plasma zinc concentrations between the two aliquots.

Other renal function data obtained in these experiments are summarized in Table 1. There were no significant effects of $\mathrm{Pb}$ on the excretion of three other cations-mag- 


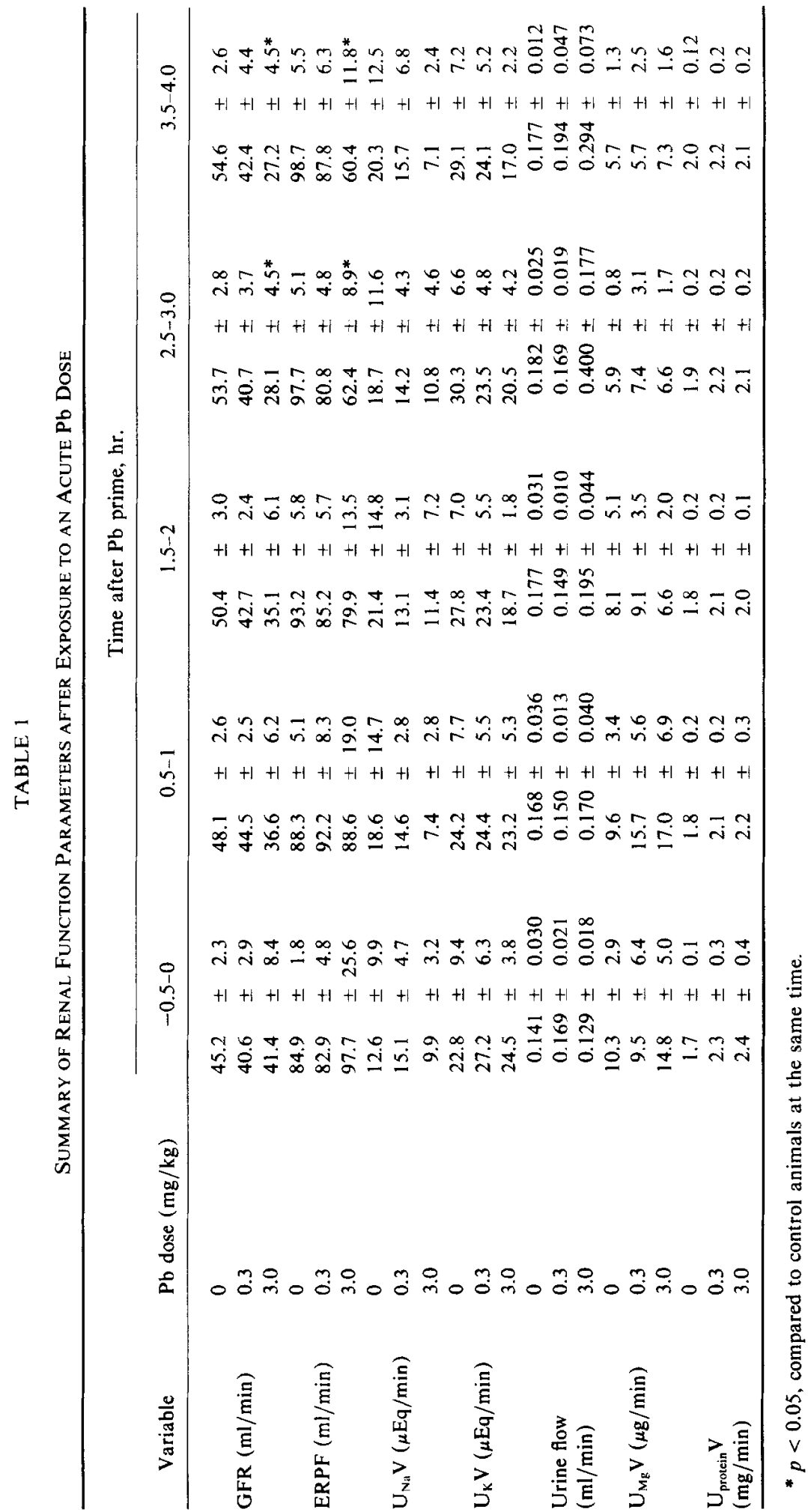


nesium, sodium, and potassium; if anything, there was a slight (but not significant) tendency for sodium excretion to decline in the last collection period after high $\mathrm{Pb}$ dose. Since most plasma zinc is protein bound, increased excretion of protein could contribute to increased urinary zinc levels; however, urinary protein excretion was similar in the three groups of animals (Table 1).

GFR was stable in the control and lowdose animals, but fell significantly in highdose animals by 3 to $4 \mathrm{hr}$ after $\mathrm{Pb}$ exposure. A similar decrease was observed for ERPF at 3 to $4 \mathrm{hr}$. There were no differences in urine flow rates between the treatment groups; the tendency for urine flow to be elevated at 3 and $4 \mathrm{hr}$ in the high- $\mathrm{Pb}$ group was due to very high values observed in one animal at those times. Throughout the experiment there were no changes within or between groups in mean arterial pressure, respiratory rate, hematocrit, or rectal temperature.

The data for the plasma concentrations of glucagon and insulin are summarized in Fig. 3. For the time controls, plasma glucagon increased slightly in the last $2 \mathrm{hr}$, whereas insulin generally decreased. There was a tendency for plasma glucagon to increase over time in both $\mathrm{Pb}$-treated groups (the increase over baseline was approximately $50 \%$ by hours 3 and 4 ), but the observed differences between this pattern and that of the time control group were not statistically significant, either by regression analysis of the entire curves or by analysis of variance at each time. The jump in glucagon at $4 \mathrm{hr}$ in the high- $\mathrm{Pb}$ group was due to a very large increase in one of the five animals. Plasma insulin concentrations remained stable throughout the experiment in the Pb-trcated groups and werc not significantly different from those of the time control groups.

\section{Series $B$}

Clearance data obtained for antidiuretic dogs using ${ }^{65} \mathrm{Zn}$ are summarized in Fig. 4;
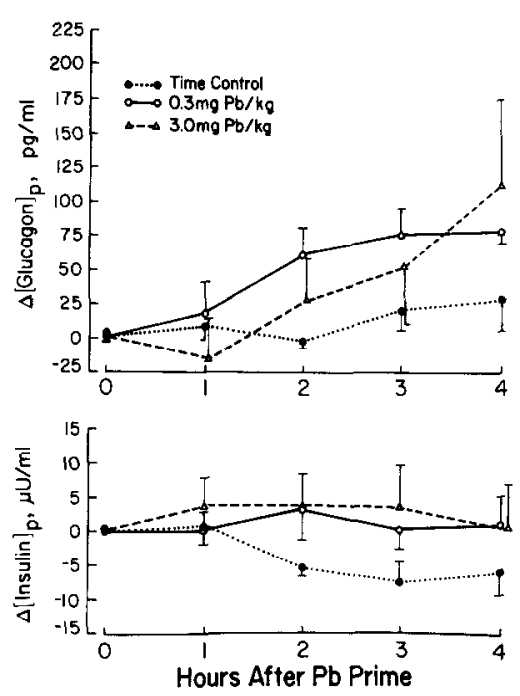

FIG. 3. Changes in plasma glucagon concentration (upper panel) and plasma insulin concentration (lower panel) for the three groups of animals. All values are presented as the change from the value during baseline collection period at $\mathbf{O} \mathrm{hr}$ after $\mathrm{Pb}$ prime (baseline insulin values for control dogs $=21.1 \pm 4.5$, low-Pb $=19.1$ \pm 6.0 , and high- $\mathrm{Pb}=19.0 \pm 4.5$; baseline glucagon values for control dogs $=133.5 \mathrm{pm} 47.1$, low- $\mathrm{Pb}=205.0$ \pm 39.3 , and high- $P b=215.2 \pm 15.9$ ). See text for statistical analysis of data.

each panel compares values obtained from control dogs with those from dogs $3 \mathrm{hr}$ after $\mathrm{Pb}$ exposure. $\mathrm{Zn}$ excretion (Fig. 4A) was 7.6fold higher in the $\mathrm{Pb}$-treated dogs; this increment is comparable to the rise in endogenous zinc excretion seen in Series A dogs. It should be reemphasized that all data for Series B dogs represent only the increment in $\mathrm{Zn}$ excretion caused by infusion of carrier $\mathrm{Zn}$ along with the ${ }^{65} \mathrm{Zn}$. The increment in plasma zinc (Fig. 4B) caused by the $\mathrm{Zn}$ infusion was not statistically significant. The increment in ultrafilterable zinc concentration (Fig. 4C) produced by the zinc infusion was two and one-half times higher in $\mathrm{Pb}$ exposed animals $(p<0.01)$; the percentage of the increment in plasma zinc which was ultrafilterable was not different between the two groups. The clearance of ultrafilterable ${ }^{65} \mathrm{Zn}$ was $1.67 \pm 0.30 \mathrm{ml} / \mathrm{min}$ in control dogs and $4.75 \pm 1.37$ after $\mathrm{Pb}$ exposure; this difference was significant $(p<0.05)$. Frac- 

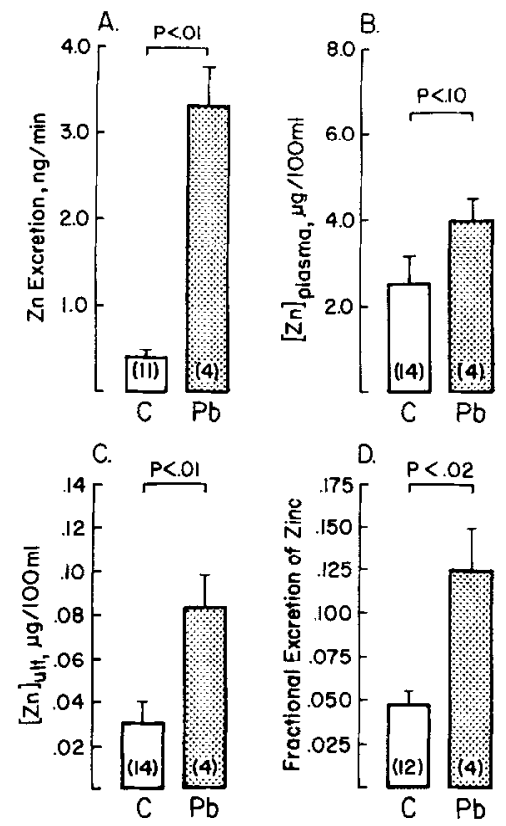

Fig. 4. Clearance data obtained in control dogs (shown in open bars) and in Pb-treated dogs (hatched bars) using ${ }^{65} \mathrm{Zn}$ infusion with $10 \mu \mathrm{g}$ carrier $\mathrm{Zn} / \mathrm{kg} / \mathrm{min}$. All values are presented as the average increment $( \pm 1 \mathrm{SE}$ ) in $\mathrm{Zn}$ values calculated from the specific activity of the infused solution. See text for details. (A) Increment in urinary $Z n$ excretion; (B) increment in plasma $\mathrm{Zn}$ concentration; (C) increment in ultrafilterable $\mathrm{Zn}$ concentration; (D) fractional excretion of $\mathrm{Zn}$ $\left(C_{\mathrm{ul}-\mathrm{Zn}} / C_{\mathrm{cr}}\right)$.

tional zinc excretion (the ratio of $C_{\text {ultzn }}$ to $C_{\text {cr }}$ ), illustrated in Fig. 4D, was threefold higher $(p<0.02)$ in the $\mathrm{Pb}$-exposed dogs than in the controls. The effects of mannitol diuresis on fractional zinc excretion in control and $\mathrm{Pb}$-exposed dogs are summarized in Fig. 5. In control dogs, mannitol (an osmotic diuretic) increased fractional excretion from $0.044 \pm 0.008$ to $0.100 \pm 0.020$ $(p<0.02)$; in $\mathrm{Pb}$-exposed dogs, fractional excretion was already elevated $(0.123$ $\pm 0.025)$ and mannitol produced only a small further (nonsignificant) elevation to $0.142 \pm 0.022$. Ultrafilterable zinc concentrations in both control and $\mathrm{Pb}$-exposed animals were not altered by mannitol.

Stop-flow analysis permits crude localization of sites of tubular reabsorption or secretion of transported substances. In pre-

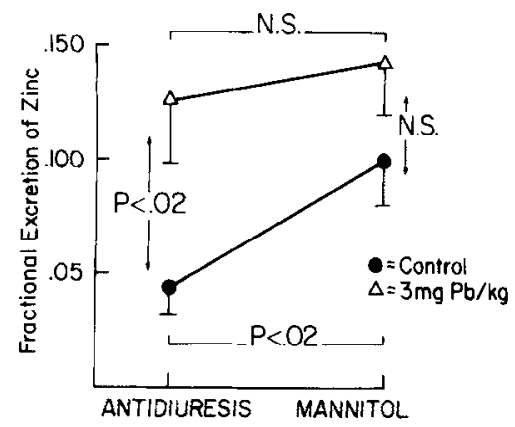

FIG. 5. The mean fractional excretion of $\mathrm{Zn}(+1 \mathrm{SE})$ for control and $\mathrm{Pb}$-treated animals during antidiuresis and osmotic diuresis (mannitol). Statistical comparison is discussed in the text.

vious studies (Victery et al., 1981), we have reported that control stop-flow patterns for $\mathrm{Zn}$ invariably showed net reabsorption in the distal nephron but not the proximal nephron; proximal reabsorption was seen only during infusion of citrate or histidine. The stop-flow pattern dipicted in Fig. 6 is typical of those obtained after $\mathrm{Pb}$ exposure in all four dogs. Prominent net $\mathrm{Zn}$ reabsorption occurred in the distal nephron segment corresponding to that for the distal minimum for sodium; for the control and $\mathrm{Pb}$-treated groups, the mean "double ratios" $(\mathrm{Zn} / \mathrm{In})$ at the nadir of the $\mathrm{Zn}$ reabsorptive dip averaged $0.24 \pm 0.07$ and $0.31 \pm 0.04$, respectively, values which are not significantly different from each other. The absolute concentrations of the carrier $\mathrm{Zn}$ administered with ${ }^{65} \mathrm{Zn}$ at the nadirs were $0.062 \pm 0.019$ vs $0.283 \pm 0.130$ $\mathrm{ng} / \mathrm{ml}$, also not significantly different. The results, therefore, fail to demonstrate $\mathrm{Pb}$-induced inhibition of distal $\mathrm{Zn}$ reabsorption. The stop-flow pattern for $\mathrm{Zn}$ shown in Fig. 6 also reveals prominent net proximal nephron secretion of $\mathrm{Zn}$; the double ratio in this experiment reached a maximum value of 1.75 and then returned to preocclusive freeflow values. After $\mathrm{Pb}$ exposure, definite net secretion of $Z n$ by the proximal nephron was observed in all four animals (double ratio $=1.94,1.75,1.6$, and 1.32 ). In contrast, definite net secretion occurred in only 4 of 14 control animals. This difference in 


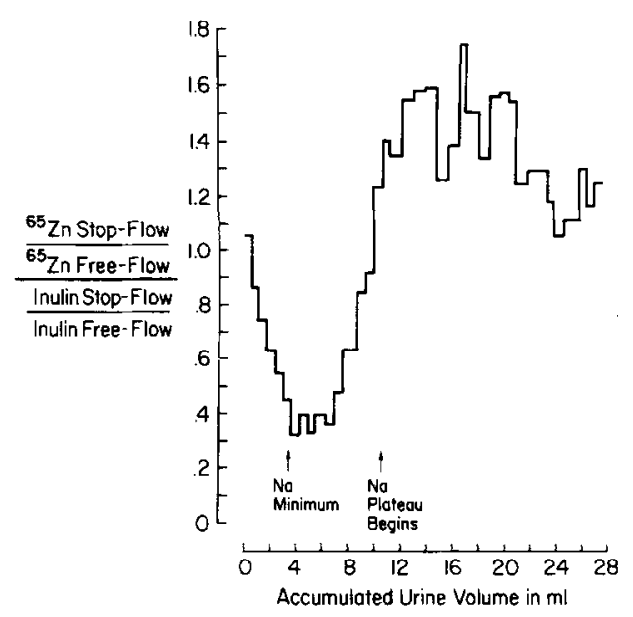

Fig. 6. A typical stop-flow pattern obtained $3 \mathrm{hr}$ after $\mathrm{Pb}$ treatment (approximately $40 \mathrm{~min}$ after initiation of mannitol diuresis). See text for description of $\mathrm{Zn}$ pattern. The sodium concentration pattern (not plotted here) provides coarse localization of nephron segments in that the minimal sodium concentration (about $3.5 \mathrm{ml}$ in Fig, 6), ie., the point of maximal reabsorption, corresponds to fluid trapped during ureteral occlusion in distal portions of the nephron (probably including collecting duct, distal tubule, and the ascending loop of Henle); the beginning of the plateau in sodium concentration (approximately 11-12 ml in Fig. 6) at its preocclusive valucs is presumed to represent fluid trapped only in the proximal portions of nephrons during occlusion.

frequency of occurrence of net proximal secretion is highly significant $(P<0.01$ by $\chi^{2}$ analysis).

\section{DISCUSSION}

These experiments demonstrate that the acute iv administration of lead to anesthetized dogs causes a dose-dependent, marked increase in urinary excretion of zinc. In this study, the effect was specific, in that there were no associated changes in urine flow or in the excretion of another divalent cation (magnesium) or of two monovalent cations (sodium and potassium). We have previously reported (Mouw et al., 1978) that, under similar experimental conditions, $3 \mathrm{mg} \mathrm{Pb} /$ $\mathrm{kg}$ produced significant increases in the urinary excretion of potassium and calcium and an increased sodium excretion of borderline significance (magnesium was not previously studied). We have no explanation for the failure to observe these changes in the present experiments; however, it must be emphasized that the previously observed changes in the other cations were, proportionally, of much lesser magnitude (approximately twofold) than the present changes in zinc excretion (seven- to eightfold) at the same dose of lead.

What are the mechanisms for the $\mathrm{Pb}$-induced changes in zinc excretion? We have previously shown that the urinary excretion of zinc is the result of glomerular filtration, tubular reabsorption, and, possibly, tubular secretion (Victery et al., 1981). Thus, the effect(s) could, theoretically, be on GFR, ultrafilterable zinc concentration, or the tubular transport pathways. An increase in GFR can be ruled out since GFR either remained unchanged or, at the high dose, decreased. Changes in the filtration of protein (carrying bound zinc) also seem very unlikely since protein excretion was not altered by lead.

Plasma zinc concentration did rise markedly at the higher dose of lead and this raised the strong possibility that ultrafilterable zinc, the important variable, might also have risen. To test this possibility, we performed the ${ }^{65} \mathrm{Zn}$ experiments. The rationale for this approach has been described in detail elsewhere (Victery et al., 1980); the crucial point validating its use is that $\mathrm{Pb}$ increased urinary excretion of acutely administered ${ }^{65} \mathrm{Zn}$ to essentially the same degree that it increased urinary excretion of endogenous zinc. This documents that the ${ }^{65} \mathrm{Zn}$ had equilibrated adequately with whatever pools of zinc were contributing to $\mathrm{Pb}$-alterable zinc excretion. The ultrafilterable data indicated that, at least at the higher dose, $\mathrm{Pb}$ did, indeed, elevate ultrafilterable zinc concentration, a phenomenon which should contribute to increased excretion. However, even at the higher dose of lead, the increase in ultrafilterable zinc was proportionally much less than the rise in zinc excretion; the 
resulting large increase in fractional excretion of zinc is a strong indication that a change in tubular transport also plays a role in the induced elevation of zinc excretion. The source of the increased plasma and ultrafilterable zinc induccd by lead is unknown but is unlikely to be the erythrocytes, as demonstrated by the in vitro experiment described in the methods section.

Stop-flow analysis was used to evaluate the possible tubular site influenced by lead and whether reabsorption was being inhibited or secretion stimulated. The major effect was clearly on the proximal nephron; the stop-flow patterns document the existence of prominent proximal secretion of zinc in all Pb-treated dogs, in contrast to the much lower frequency of such secretion seen in control dogs. However, this finding does not conclusively prove that increased proximal secretion is the effect produced by lead; decreased proximal reabsorption is just as likely a possibility. If bidirectional transport normally exists for zinc in the proximal nephron (Victery et al., 1981), inhibition of reabsorption would permit secretion, unopposed, to become manifest. Accordingly, the present data do not permit a distinction between $\mathrm{Pb}$-induced stimulation of secretion or inhibition of reabsorption. Theoretically, the latter would seem the more likely, assuming that lead and zinc compete for a transport pathway. Indirect evidence also favoring inhibition of proximal reabsorption is the fact that lead had relatively little further enhancing effect on zinc excretion when the latter had already been raised by mannitol diuresis.

Whether lead influences proximal zinc transport indirectly or via a direct renal effect is not answered by the present experiments. They do, however, rule out the possibility that increased plasma glucagon or decreased plasma insulin is responsible, since these hormones showed little if any, alteration during $\mathrm{Pb}$ exposure. This failure to increase is, however, of considerable interest in another context; it suggests that the abil- ity of lead to block the hepatic clearance of renin (Goldman et al., 1980), another protein hormone, may be a highly specific effect.

Finally, the most important question for future investigation raised by these experiments is whether chronic exposure to low doses of lead might similarly elevate zinc excretion. Such an effect would be in addition to any $\mathrm{Pb}$-induced inhibition of gastrointestinal zinc absorption and might importantly contribute to the development of zinc deficiency.

\section{ACKNOWLEDGMENTS}

This investigation was supported by NIOSH Grant R01-OH-00913. Winona Victery was a postdoctoral fellow supported by the National Institute of Environmental Health Sciences.

The authors wish to acknowledge the assistance of Judith Blumberg in performing the statistical analyses.

Some of these data were presented at the Society of Toxicology meeting, San Diego, CA, March 2, 1981.

\section{REFERENCES}

Cantrell, A. C., Kilroe-Smith, T. A., Simoes, M. M., AND Border, E. A. (1977). The effect of zinc and $\mathrm{pH}$ on the behaviour of $\Delta$-aminolevulinic acid dehydratase activity in baboons exposed to lead. Brit. J. Ind. Med. 34, 110-113.

CERKLEWSKI, F. L. (1979). Influence of dietary zinc on lead toxicity during gestation and lactation in the female rat. J. Nutr. 109, 1703-1709.

CerkLewsKi, F. L., AND Forbes, R. M. (1976). Influence of dietary zinc on lead toxicity in the rat. $J$. Nutr. 106, 689-696.

Davis, J. R., AND AVRaM, M. J. (1978). A comparison of the stimulatory effects of cadmium and zinc on normal and lead-inhibited human erythrocytic $\Delta$ Aminolevulinic acid dehydratase activity in vitro. Toxicol. Appl. Pharmacol. 44, 181-190.

El-Gazzar, R. M., Finelli, V. N., Bolano, J., and Petering, H. G. (1978). Influence of dietary zinc on lead toxicity in rats. Tox. Lett. 1, 227-234.

Goldman, J. M., Vander, A. J., Mouw, D. R., Keiser, J. M., AND Nicholls, M. G. (1980), Multiple short-term effects of lead on the renin-angiotensin system. J. Lab. Clin. Med. 97, 251-263.

hayaski, M., Floyd, J. C., Pex, S., and fajans, S. S. (1977). Insulin, proinsulin, glucagon, and gastrin in pancreatic tumors and in plasma of patients with 
organic hyperinsulinism. Clin. Endo. Metab. 44, 681 694.

Hsu, F. S., Krook, L., Pond, W. G., and Duncan, J. R. (1975). Interactions of dietary calcium with toxic levels of lead and zinc in pigs. J. Nutr. 105, 112-118.

MALVIN, R. L., AND WILDE, W. S. (1973). Stop-flow technique. In Handbook of Physiology: Renal Physiology (J. Orloff and R. W. Berliner, eds.), pp. 119128. Am. Physiol. Soc., Washington, D.C.

Mauras, Y., and Allain, P. (1979). Inhibition of delta-aminolevulinic acid dehydratase in human red blood cells by lead and activation by zinc or cysteine. Enzyme 24, 181-187.

Meredith, P. A., Moore, M. R., AND Goldberg, A. (1977). Effects of aluminum, lead, and zinc on $\Delta$ aminolevulinic acid dehydratase. Enzyme 22, 22-27.

Mouw, D. R., VANDER, A. J., Cox. J.. AND FleISCher, N. (1978). Acute effects of lead on renal electrolyte excretion and plasma renin activity. J. Lab. Clin. Med. 46, 435-447.

Pek, S., Fajans, S. S., Floyd, J. C., Knopf, R. F., AND CONN, J. W. (1972). Failure of sulfonylureas to suppress plasma glucagon in man. Diabetes 21, 216-223.

Seth, T. D., Agarwal, L. N., Satija, N. K., and HASAN, M. Z. (1976). The effect of lead and cadmium on liver, kidney, and brain levels of cadmium, copper lead, manganese, and zinc, and on erythrocyte
ALA-D activity in mice. Bull. Environ. Contam. Toxicol. 16, 190-196.

Thawley, D. G., Willoughby, R. A., McSherry, B. J., Macleod, G. K., MacKay, K. H., and Mitchell, W. R. (1977). Toxic interactions among $\mathrm{Pb}, \mathrm{Zn}$, and $\mathrm{Cd}$ with varying levels of dietary $\mathrm{Ca}$ and Vitamin D: Hematological system. Environ. Res. 14, 463-475.

Vander, A. J., Taylor, D. L., Kalitis, K., Mouw, D. R., AND VICTERY, W. (1977). Renal handling of lead in dogs: Clearance studies. Amer. J. Physiol. 233, F532-538.

VICTERY, W., VANDER, A. J., AND MOUW, D. R. (1979a). Effect of acid-base status on renal excretion and accumulation of lead in dogs and rats. Amer. J. Physiol. 237, F398-F407.

Victery, W., VANDER, A. J., AND Mouw, D. R., (1979b). Renal handling of lead in dogs: Stop-flow analysis. Amer. J. Physiol. 237, F408-414.

Victery, W., LeVENSON, R., AND VANDER, A. J. (1980). Effect of glucagon on zinc excretion in anesthetized dogs. Amer. J. Physiol. 240, F299-F305.

VICTERY, W., SMITH, J. M., AND VANDER, A. J. (1981). Renal tubular handling of zinc. Am. J. Physiol. (in press).

Willoughby, R. A., MacDonald, E., McSherry, B. J., AND BRown, G. (1972). Lead and zinc poisoning and the interaction between $\mathrm{Pb}$ and $\mathrm{Zn}$ poisoning in the foal. Cand. J. Comp. Med. 36, 348-359. 